\title{
LUDMYŁA MARCZUK
}

\section{Koncept wojna w kronikach Bukowiny: dzienniku Iwana Bażanskiego oraz bukowińskim kalendarzu prawosławnym}

\section{Abstrakt}

W pracy dokonano analizy lingwokulturemu wojna na materiale ukraińskiej prozy, wykorzystując narzędzia badawcze lingwistyki kognitywnej, lingwistyki kulturowej oraz socjolingwistyki. Takie podejście umożliwia modelowanie oraz odwzorowanie strukturalnych elementów świadomości uczestników-nadawców, bazując na analizie konceptów, modeli metafor oraz stereotypów, które dają podstawy wyjaśnienia omawianego pojęcia.

Słowa kluczowe: metafora kognitywna, lingwokulturemy, koncept, lingwistyka kognitywna, model metafory.

\section{Wstęp}

Język jest nie tylko środkiem komunikowania się, instrumentem porozumiewania się, ale przede wszystkim źródłem wiedzy o człowieku i jego sposobach konceptualizacji świata, bo - jak zauważa Anna Wierzbicka:

język jest narzędziem służącym do wyrażania znaczeń. Myślimy, czujemy, postrzegamy — dążymy do wyrażania naszych myśli, uczuć i spostrzeżeń. Zazwyczaj - choć nie jest to regułą - wyrażamy je, ponieważ pragniemy je dzielić z innymi ludźmi. Język jest nam potrzeby do utrwalenia naszych myśli, często - do ich uporządkowania. Piszemy pamiętniki, robimy notatki i zapiski w kalendarzach. Złorzeczymy i wykrzykujemy — nawet wtedy, gdy nikt nas nie słucha. Wspólnym mianownikiem tych wszystkich sposobów użycia języka nie jest komunikacja, lecz znaczenie. (Wierzbicka 1991: 7)

Jednym z najaktualniejszych problemów badawczych współczesnego językoznawstwa ukraińskiego jest analiza określonych konceptów, które są jednym ze sposobów rekonstrukcji językowego oraz konceptualnego obrazu świata. Zarówno Witalij Żajworonok (Жайворонок 1996), jak i Tetiana Kosmeda (Космеда 2010) uważają konceptualny obraz świata (KOS), zawierający elementy werbalne oraz pozawerbalne, za kategorię nadrzędną w stosunku do językowego obrazu świata (JOS). 


\section{Przyjmuję, że KOS to}

całościowy obraz świata, stanowiący podstawę ludzkiego światopoglądu, tzn. wyraża zasadnicze właściwości świata w postrzeganiu człowieka. Są one wynikiem jego duchowości (Селіванова 2006: 260),

\section{z kolei JOS rozumiem jako}

wyobrażenia przedmiotów, zjawisk, wydarzeń, strategii życiowych i scenariuszy zachowania, które są przekazane za pomocą znaków językowych, kategorii, zjawisk językowych, będących semiotycznym rezultatem koncepcyjnej reprezentacji rzeczywistości w etnoświadomości. W konceptualnej kategoryzacji świata JOS nie jest izomorficzny, ale jest jego podsystemem, który arbitralnie i konwencjonalnie utrwala niektóre struktury poznawcze. Nie wszystkie jednak kategorie językowe są wynikiem konceptualnej kategoryzacji. (Селіванова 2006: 365)

„Koncept” (od łac. conceptus - 'pojęcie') to

wielopoziomowa, informacyjna struktura świadomości, zorganizowana w pewien sposób jednostka pamięci, zawierająca zbiór werbalnych i niewerbalnych informacji o przedmiocie poznania, nabytych dzięki wzajemnemu oddziaływaniu pięciu psychicznych funkcji świadomości i pozaświadomości. (Селіванова 2006: 256)

W niniejszej pracy traktuję „koncept” oraz „lingwokulturem” jako synonimy ${ }^{1}$. W opracowaniu odwołuję się do ustaleń lingwistów ukraińskich, których zainteresowania naukowe koncentrują się wokół problemów konceptualizacji wybranych fragmentów językowego obrazu świata (Жайворонок 1996), zagadnień metaforyzacji (Космеда 2010), a także terminologicznych aspektów lingwistyki kognitywnej (Яворська 2000; Селіванова 2006; Іващенко 2006; Радзієвська 2010).

Artykuł ten wpisuje się w nurt badań językoznawczych, których celem jest opisanie zawartych w języku sposobów postrzegania, porządkowania oraz wartościowania świata, oraz stanowi rekonstrukcję niewielkiego fragmentu językowego obrazu świata - konceptu wojny na przykładzie dziennika-kroniki zatytułowanegо Війна: Щоденник-хроніка буковинського педагога та письменника (Wојпа: dziennik-kronika bukowińskiego nauczyciela i pisarza) autorstwa Iwana Bażanskiego, a także zbioru artykułów pod tytułem Невідома війна. Перша світова війна на сторінках Правоставного буковинського календаря 1914-1918 (Nieznana wojna. Pierwsza wojna światowa na łamach bukowińskiego kalendarza prawosławnego 1914-1918). Obie publikacje łączy temat wojny i miejsce, w którym się rozgrywa: Księstwo Bukowiny, znajdujące się wówczas w granicach Austro-Węgier. Do pewnego stopnia wspólne są też losy obu kronik. Czytelnicy mogli zapoznać się z nimi dopiero w XXI wieku: $\mathrm{z}$ dziennikiem Iwana Bażanskiego w 2006, zaś z bukowińskim kalendarzem prawosławnym w 2007 roku, kiedy to dzieła uporządkowane przez badaczy zostały szerzej udostępnione.

${ }^{1}$ Jako pierwszy pojecie lingwokulturemu wprowadził Władimir Worobjow. Zdefiniował on lingwokulturem jako całościową, zintegrowaną jednostkę, łączącą w sobie językowe i pozajęzykowe (pojęciowe i przedmiotowe) treści. Łączy formę (znak) oraz treść (znaczenie językowe i tło kulturowe). Ze względu na strukturę może być oddzielnym leksemem, lecz także całym tekstem (Воробьев 1994: 76). 
Słownik etymologiczny języka rosyjskiego Maxa Fasmera podaje, że leksem wojna po „ukr. війна; rusko-cerkiewno-słow. воина; bułg. война; słowen. vójna; czes., słowac. vojna; pol. wojna; głuż., dłuż. wojna" jest powiązany z воин oraz pokrewnymi słowami, „w starosłowiańskim повинати 'zdobyć. Pokrewne z lit. vejšù, výti 'gonić, prześladować; łot. vēnor, āri 'polować; irl. faid 'dicz'; łac. hroelium od *provoliom. Stąd wojna, wojsko" (Фасмер 1967: 185).

Strukturę znaczeniową słowa, to jest jego centrum znaczeniowe jako stabilny rdzeń pojęciowy oraz konotacje, można wskazać przez analizę kontekstów, w jakich słowo wojna się pojawiło. Najlepiej ujawnia się to w paremiologii. Oto wybrane przykłady przysłów, powiedzeń, aforyzmów o wojnie:

- Війна, війна! I знов криваві ріки! I грім гармат, і шаблі дзвін. Могили, сироти, каліки/ І сум покинутих руїн ${ }^{2}$;

- Війна людей їсть, кров'ю запиває $\epsilon^{3}$;

- Хочеш миру - готуйся до війни ${ }^{4}$;

- Не хвались ідучи в бій, а хвались ідучи з бою5.

Na podstawie analizy etymologii słowa wojna oraz wyrazów pokrewnych i przysłów można wydzielić następujące cechy semantyczne:

- brak spokoju, konflikt, walka zbrojna między narodami, warstwami społecznymi;

— walka na polu boju;

- stan wrogości między państwami;

- wojna przemysłowa, gospodarcza;

- spór, kłótnia z kimś.

Ogólny kontekst emocjonalny lingwokulturemu wojna można przedstawić jako: 'straszne nieszczęście, którego należy unikać, jest związane z kłamstwem, zdradą, utratą życia, zdrowia i bliskich. Jednak pojęcie wojny interpretowane jest na różne sposoby, więc ludzie chcą znać prawdę o wojnie’.

Przeszło sto lat temu światem wstrząsnęła I wojna światowa. Nie ominęła ona Księstwa Bukowiny ${ }^{6}$, kraju koronnego Austrii, położonego na granicy z carską Rosją. Mieszkańcy Bukowiny jako jedni z pierwszych odczuli ciężar zbrojnego kon-

2 „Wojna, wojna! I znów krwawe ręce! I grzmot armat, i szabel dzwon. Mogiły, sieroty, kaleki/ I szum opuszczonych ruin” - O. Oleś, Крилаті вирази, вислови і ц̧итати про життя і смерть, http://www.ukrlib.com.ua/encycl/viraz/printout.php?id=11 (dostęp: 15.03.2017).

3 „Wojna ludzi je, krwią zapija” - Вислови, афоризми, загадки, http://vislovi.in.ua/prikazki-temi/54-vijsko.html (dostęp: 15.03.2017).

4 „Chcesz pokoju - szykuj się do wojny” (łac. Si vis pacem, para bellum).

5 „Nie chwal się, idąc w bój, ale chwal się powracając z boju” - Вислови, афоризми, загадки...

${ }^{6}$ Księstwo Bukowiny (niem. Herzogtum Bukowina, ukr. Герцогство Буковина) - istniejący w latach 1849-1918 kraj koronny Cesarstwa Austrii, obejmujący obszar Bukowiny. 4 marca 1849 roku Bukowina została odrębnym krajem koronnym Austrii jako księstwo i przetrwała w tej postaci do rozpadu monarchii w 1918 roku. Wówczas stolicą administracyjną Księstwa były Czerniowce. Obecnie Bukowina podzielona jest między Rumunię (Bukowina południowa) i Ukrainę (Bukowina północna) — https://pl.wikipedia.org/wiki/Ksi\%C4\%99stwo_Bukowiny (dostęp: 5.07.2017). 
fliktu, dlatego nie może dziwić, że ówczesne wydarzenia zajmują ważne miejsce w świadomości twórców bukowińskich: pisarzy, poetów, a także ludzi niezwiązanych zawodowo z pisaniem, ale chcących utrwalić własne przeżycia i podzielić się $\mathrm{z}$ innymi własnymi doświadczeniami z czasu wojny.

\section{Koncept wojna w dzienniku-kronice Iwana Bażanskiego}

Z Bukowiną związany był Iwan Bażanski (1863-1933) — oryginalna postać w ukraińskiej literaturze z końca XIX i początku XX wieku. Twórca pochodził z miejscowości Waszkowce koło Czerniowiec; był pisarzem, dramaturgiem, folklorystą, nauczycielem oraz wychowawcą, a także pierwszym fotografem amatorem na $\mathrm{Bu}-$ kowinie. Nie stronił od spraw publicznych, ale głównie zajmował się pisaniem. Jest znany przede wszystkim jako pisarz i poeta, chociaż jest też autorem publikacji pedagogicznych oraz wykładów edukacyjnych. Ukoronowaniem jego twórczości jest dziennik-kronika, pisany w latach I wojny światowej (1914-1918) i po jej zakończeniu (do 1922 roku), w którym opisuje wydarzenia ze swego życia i tej części kraju, w której przyszło mu przetrwać wojnę. To unikalna publikacja, nie do przecenienia dla językoznawców, folklorystów, kulturoznawców, etnografów oraz wszystkich badaczy zajmujących się Bukowiną. Niestety kronika częściowo została zniszczona, a jej fragmenty - utracone bezpowrotnie. Oto fragment z zachowaniem oryginalnego zapisu:

Тепер настала для Вашківців страшна година. Що не знищили гарматні москальські кулі, то знищили і зграбували самі москалі. Наче яка повінь, ввалилися вони до міста, грабуючи та розбиваючи все по хатах та знущаючись над жінками та дівчатами... Багато будинків ушкодили гарматні кулі, 4 згоріли від шрапнелі до тла... Кулі неприятеля бриніли як бджоли в стіни школи та дах...7 (Бажанський 2006: 38)

Bażanski regularnie robił notatki, zapisywał szczegółowo wydarzenia ze swojego życia podczas wojny. Do 1919 roku wpisy są liczne i drobiazgowe. Od 1919 roku pojawiają się już przeważnie krótkie informacje, których częstotliwość zmniejsza się w następnych latach: 1920 roku - cztery wpisy, 1921 — dwa, a w 1922 - tylko jeden.

Mimo że bukowińska kronika jest cennym źródłem informacji, długo pozostawała nieznana na Bukowinie. Niektóre jej fragmenty były publikowane w czasopismach, jednak całość zachowanego tekstu została udostępniona szerokiemu gronu odbiorców dopiero w 2006 roku dzięki redaktorowi naukowemu Wołodymirowi Zapołowskiemu oraz profesorowi Ołeksandrowi Ohujowi, który uporządkował

7 „Teraz nadszedł dla Waszkowców straszny czas. Co nie zniszczyły moskalskie kule, to zniszczyli i zrabowali sami Moskale. Jak powódź wdarli się do miasta, rabując i rozbijając wszystko po domach i napastując na kobiety i dziewczęta... Wiele budynków zostało uszkodzonych przez kule armatnie, 4 spaliły się od szrapneli do cna... Kule nieprzyjaciela jak pszczoły brzęczały w ścianie szkoły i dach..." Fragmentów przekładu dziennika Iwana Bażanskiego na język polski dokonała Iryna Procyk. 
kronikę. Oprócz tekstu dziennika (440 wpisów) książka obejmuje: wstęp, artykuł O. Ohuja, dwa dodatki: słowniczek terminów oraz dialektyzmów, a także streszczenia w języku niemieckim, angielskim i rosyjskim.

Iwan Bażanski, będąc bezpośrednim świadkiem wydarzeń, w swojej kronice-dzienniku nie tuszował okropieństwa wojny; przeciwnie, uważał za swój obowiązek pokazać przyszłym pokoleniom jej straszne oblicze. Opisując walkę Austriaków i Rosjan z 24 września 1914 roku, wskazywał najpierw na rozpacz i strach zwykłych mieszkańców podczas spotkania z żołnierzami, ich dezorientację, niezdolność do racjonalnego myślenia i ratowania swojego życia za wszelką cenę, a na końcu instynktowną ucieczkę mimo wszystko. We fragmencie przedstawiającym zachowanie mieszkańców w popłochu pisał:

„Козаки, Козаки!” - зачали люди кричати і все, що було на торговиці розлетілося на всі боки, полишаючи на місці вози і худобу і все, що мали. Билися горшки, яйця, розливалося молоко, що повиносили на продаж: метушня не до описання 8 . (Бажанський 2006: 34)

Niektóre opisane sytuacje samemu autorowi wydają się nierealne. Czytelnik odnosi wrażenie, że nadmiar szybko toczących się zdarzeń, a przede wszystkim brak odpowiedniej reakcji na nie, powoduje u Bażanskiego zaburzenia świadomości. Trudno było przyzwyczaić się do wojny, w pełni odnaleźć się w zmienionych warunkach, kiedy żyje się w ciągłym strachu. Oto jeden z krytycznych momentów dobrze ilustrujący takie zachowanie:

Тут оден одного застрелив, тут кричать «алярм», бо неприятель в Залучу, військо біжить в шанці, трен тікає, прострілений конає, єго залишають самого, лиш я з ним, тут вже й стрілянина, сальва, ціле нещастя... Але за час все перемінилося. Москалі десь зникли, стріляння втихло, застріленого відвезли до трупарні, військо повернуло, знов гаразд 9 . (Бажанський 2006: 3)

Autor pokazuje okropności wojny poprzez zachowania żołnierzy Tekińskiego Pułku Kawalerii, którzy w czerwcu 1916 roku jawnie i bezkarnie plądrowali i rabowali nawet mienie szkolne. Prezentuje ich jako ludzi nieuczciwych, pozbawionych człowieczeństwa, którzy żyją w kłamstwie, prześladują zwykłych mieszkańców, by zaspokoić swoje żądze, dla prymitywnego „nużno” (ros. potrzeba). W jednym z wpisów w maju 1917 roku Bażanski wspomina kaukaskich kozaków rozlokowanych w szkole. W kilku słowach przedstawia ich wygląd, zwyczaje, sposób życia i kulturę:

8 „»Kozacy Kozacy!« — ludzie zaczęli krzyczeć i wszystko, co było na targowisku, porozrzucali we wszystkie strony, pozostawiając na miejscu wozy, bydło i wszystko, co mieli. Przewiezione na sprzedaż garnki i jaja potłukły się, mleko się rozlało: zamieszanie trudno nawet opisać”.

9 „Tu jeden drugiego zestrzelił, tu krzyczą »alarm«, ponieważ wróg jest już w Załuczu, wojsko biegnie w okopy, obóz wojskowy ewakuuje się, postrzelony kona, zostawiają go samego, tylko ja z nim, tutaj już strzelanina, salwa, całe nieszczęście... Ale z czasem wszystko się zmieniło. Moskale gdzieś zniknęli, strzały ucichły, zastrzelonego przewieźli do kostnicy, wojsko wróciło, znowu wszystko w porządku”. 
...Жиють патріархальним ладом..., а жінку собі купують. Письма свого не мають, вживають російського, але говорять по-осетинськи ${ }^{10}$. (Бажанський 2006: 139)

Powrót żołnierzy austriackich na Bukowinę 13 października 1917 roku przyniósł pewne zmiany. Bażanski mimochodem wspomina, że władze austriackie po odzyskaniu utraconych terenów jak najszybciej zaczynają przywracać porządek, mają zamiar odbudować mosty i tory. Coraz częściej jednak skupia się na akcentowaniu okrucieństwa wojny: porównuje człowieka do zwierzęcia, wielokrotnie ubolewa, że za dużo zła jedni wyrządzają drugim, wciąż nie może uwierzyć, że ludzie są zdolni do takiego zachowania. Na przykład w notatce z 21 listopada 1917 roku czytamy:

Чоловік наостанок все-таки звірина - це показала війна. [...] Три роки війни, і чоловік став знов тим, чим був перед сотками літ - звіриною ${ }^{11}$. (Бажанський 2006: 156-157)

Autor wskazuje jednak na to, że proces ten odbywa się pod przymusem, wbrew woli człowieka:

Давно сам чоловік був звірина, а тепер єго роблять звіриною, травлять один на одного ${ }^{12}$. (Бажанський 2006: 157)

Jest oburzony sytuacją w Europie, uważa, że nie może być człowiekiem kulturalnym ktoś, kto podziwia okropności wojny:

Не все одно читати по газетах про війну, а бачити її очима; і знов не все одно, хто ії бачить. $Є$ ще люди, що називаються «культурні» люди, що любуються в тім, як бачать широке поле, засіяне порозриваними людськими тілами, закрашене людською кровію, як чує стогін, зойк тисячий конаючих, як видить, як в небо здіймаються чорні стовпи диму з горючих сіл ${ }^{13}$. (Бажанський 2006: 152)

Bażanski ma nadzieję, że sprawcy wojny zapłacą za miliony ludzi, którzy stracili życie:

Ваші кости будуть проклинати ще в десятім поколінні ${ }^{14}$. (Бажанський 2006: 52)

Autora zaskakuje płynność ludzkiego życia. W zawierusze wojny znikają wszystkie codzienne zmartwienia, ludzie myślą o tym, jak się uratować, nawet kosztem utraty osobowości. Każde życie jest cenne, chociaż w takich okolicznościach śmierć jest zwykła, ale czas mija zbyt szybko:

$10, \ldots$.̇̇yą w układzie patriarchalnym... a żonę sobie kupują. Pisma swojego nie mają, używają rosyjskiego, ale mówią w języku osetyńskim”.

11 „Człowiek w końcu to jednak zwierzę - to pokazała wojna. [...] Trzy lata wojny i człowiek stał się znów tym, czym był przed setkami lat - bestią".

12 „Kiedyś człowiek sam był bestią, a teraz z niego robią bestię, podburzają jednego przeciwko drugiemu".

13 „Czytać w gazetach o wojnie i zobaczyć ją na własne oczy to nie jest to samo; i znów to nie jest wszystko jedno, kto to widzi. Są jeszcze ludzie, którzy się ludźmi »kulturalnymi«, a podziwiają szerokie pola z porozrywanymi ludzkimi ciałami, pomalowane ludzką krwią, jak słychać jęk, krzyk tysięcy umierających, kiedy widać, jak do nieba wznoszą się słupy czarnego dymu płonących wsi”.

14 „Wasze kości będą przeklinać jeszcze do dziesiątego pokolenia”. 
Чоловік не тямить, коли яка днина, не знає, коли проминула зима, весна. Причина цему відай та, що мало думається про минувшість, все тілько теперішність та будучність перед очима ${ }^{15}$. (Бажанський 2006: 56)

Pisarz oddaje stan psychiczny człowieka, który nie jest przyzwyczajony do okropności wojny, do stałej śmierci i nieszczęścia:

На обличчу всякого страх, розстроєння, непевність. Якийсь неописаний тягар, якась дивна нудьга, трі-вога налягла на всіх... Коли вже раз кінець лиху?! ${ }^{16}$ (Бажанський 2006: 52)

Zauważa, że wojna zasiała niezgodę w społeczeństwie, podzieliła ludzi. Nie przejmują się oni brakiem informacji, wiadomościach o krewnych:

[...] війна розбила кожду родину. По всіх кінцях світа розбрилися люди і - вбиваються... ${ }^{17}$ (Бажанський 2006: 83)

Wiele zapisów pokazuje fotograficzną metodę przedstawiania rzeczywistości, widoczne są cechy naturalizmu. Bażanski stara się w swych pracach dokładnie odzwierciedlać głównie życie rolników. Psychologia osoby przedstawiona została na poziomie społecznym i gospodarczym - na poziomie instynktów, tradycji, norm moralnych, wstrząsów życiowych. Autor jest rozczarowany tym, że nikt nie pragnie pokoju:

середа 29.12.1915. Страшній і небувалій досі світовій війні не буде відай кінця так скоро. Багато вже пишуть і говорять посли в різних парламентах про мирі всі бажають кінця цьому страшному кровопролиттю, однак ніхто не хоче починати ${ }^{18}$. (Бажанський 2006: 74)

Ostatnie wpisy w dzienniku są przeważnie krótkie i rzadkie. Autor odnosi się w nich do brutalnej dominacji Rumunów i pogorszenia się życia na Bukowinie. Notatki pełne są pesymizmu. Bażanski stracił wiarę we władzę i sprawiedliwość. Widzi swoją przyszłość w ciemnych barwach, przez co rozgoryczony pod datą 6 stycznia 1922 roku napisze:

Жиється! Бо муситься жити. Яке те наше життє!? Як в якій сліпій вулиці. А темно-темно!... ${ }^{19}$ (Бажанський 2006: 204)

Jeszcze innym rozumieniem wojny, a raczej konsekwencji wojny, jest rewolucja w Rosji, którą autor tak oto opisuje w swoim dzienniku:

15 „Człowiek nie rozumie, jaki jest dzień, nie wie, kiedy minęła zima, wiosna. Powodem jest chyba to, że mało myśli o przeszłości, lecz tylko o teraźniejszości i w przyszłość skierowany jest wzrok”.

16 „Na twarzy każdego strach, lęk, niepewność. Jakiś nieopisany ciężar, jakaś dziwna melancholia, niepokój opętał wszystkich... Kiedy już to nieszczęście się skończy?!”

17 „[...] wojna zniszczyła każdą rodzinę. We wszystkie krańce świata rozeszli się ludzie — i zabijają siebie..."

18 „[Ś]roda 29.12.1915. Straszna i bez precedensu wojna światowa nie skończy się, jak widać, tak szybko. Wiele zostało napisane i wypowiedziane w różnych parlamentach o pokoju, wszyscy chcą, aby skończył się ten straszny rozlew krwi, ale nikt nie chce to rozpocząć”.

19 „Żyje się! Bo musi się żyć. Jakie jest to nasze życie? Jak w jakiejś ślepej ulicy. A jak ciemno jest!...” 
3 бесід міністрів і інших перворядних осіб теп. рос. /револ./ правительства видко, що революція в Росії аж тепер на добре розгоряється після слів газети. Росія тепер стоїть в полосі испітаній (четвер 10.05.1917) ${ }^{20}$. (Бажанський 2006: 137)

Autor relacjonuje zdobycie rodzinnej wsi Waszkowce - najpierw przez Moskali, a potem kolejno przez kozaków kaukaskich (Osetyńczyków), Polaków (określa ich jako „naszą armię"), oddziały wojsk niemieckich itd. Wspomina także o Ukraińskiej Galicyjskiej Armii, opowiadając się jednoznacznie po stronie walczącej o niepodległość Ukrainy:

По домах провівають фани, по церквах правлять молебні; Мир з Україною! - Українцям втіха; Україна вільна, независима! Українська земля під Австриєю не піде під Польщу! ${ }^{21}$ (Бажанський 2006: 168)

Pojęcie wojna, nie tylko w kontekście I wojny światowej, jest jednym z najistotniejszych na Bukowinie i w twórczości pisarzy oraz poetów związanych z tym terenem. Często - tak jak w wypadku Bażanskiego - wojna jest postrzegana przez pryzmat osobistego doświadczenia autora. Jest ona wówczas jednoznacznie oceniana negatywnie.

\section{Koncept wojna w bukowińskim kalendarzu prawosławnym}

Temat wojny obecny jest również w zbiorze artykułów zatytułowanym Невiдома війна. Перша світова війна на сторінках Правоставного буковинського календаря 1914-1918 (Nieznana wojna. Pierwsza wojna światowa na łamach Bukowińskiego kalendarza prawosławnego 1914-1918) (dalej: Календар). Szczegółowo opisano w nim dzieje Bukowiny i jej mieszkańców. Celem zebranych w nim tekstów było przede wszystkim wzmocnienie ducha walki żołnierzy pochodzenia ukraińskiego, którzy służąc w armii austriackiej, marzyli o zjednoczeniu wszystkich ziem ukraińskich i własnym państwie, dlatego nie brakuje w nich opisów heroicznej postawy ukraińskich ochotników.

Kalendarz przepełniony jest ideą miłości do Ukraińców i podziwem dla ich waleczności. Nie brakuje też odniesień do walk z Rosjanami i skomplikowanych stosunków z carską Rosją:

Таким чином Росія своєю заборчою політикою і воєнним загрожуванням сусідів висунула сама на чергу дня українське питаннє, яке сяк або так буде полагоджене в недалекім

20 „Z rozmów ministrów i innych osób przewodniczących w obecnym urzędzie rewolucyjnym jest oczywiste, że rewolucja w Rosji dopiero na dobre się rozkręca po słowach gazety. Rosja jest obecnie u progu prób (czwartek 10.05.1917)".

21 „Na budynkach powiewają flagi, po cerkwiach modlą się; Pokój z Ukrainą! - pocieszenie Ukraińcom; Ukraina jest wolna, niezależna! Ukraińska ziemia pod Austrią nie pójdzie pod Polskę". 
може часі. $€$ добрі вигляди, що вже ся війна визволить з московського ярма частину українських земель ${ }^{22}$. (Календар 2007: 133)

Porównując wydarzenie historyczne - I wojnę światową - z dzisiejszą sytuacją na Ukrainie, można stwierdzić, że istnieje semantyczne podobieństwo między wojną z 1914 roku a tą toczącą się obecnie. Nadal bowiem aktualne są słowa z bukowińskiego kalendarza prawosławnego:

Одно певне, що український нарід не загине, як не загинув до тепер і його ще чекає блискуча будучність ${ }^{23}$ (Календар 2007: 133)

albo

Ми бачили, що сама природа поставила Україну на таке місце серед цілого світа, що вона висунена тепер історичними невідхильними подіями на перше місце ${ }^{24}$. (Календар 2007: 134)

W kalendarzu nie brakuje bardziej ogólnych stwierdzeń dotyczących wojny:

Настане для нас велике свято після таких терпінь, свято відродження нашої душі і серця та свято відродження національного 25 (Календар 2007: 107),

a także informacji szczegółowych o mieszkańcach Bukowiny i ich sytuacji:

А як війна в східній Галичині і на Буковині грозила страшним нещастям, то і тоги не вдало ся російським комендантам і посіпакам здушити ті між народом глибоко вкорінені династичні почування, що їх викохали провідники народу, хоч добрі сусіди противне торочать ${ }^{26}$.

(Календар 2007: 127)

\section{Zakończenie}

Lingwokulturem wojna jest przekazywany w kronikach I wojny światowej głównie przez leksemy o negatywnej konotacji. Jednocześnie emocjonalny koncept wojna jest reprezentowany poprzez znaczną liczbę jednostek leksykalnych, poza rzeczownikiem wojna, są to między innymi: katastrofa, ogień, pociski, morderstwo, krew, rozlew krwi, emigracja, wróg. Wśród leksemów o pozytywnej ocenie znajdują się

22 „W ten sposób Rosja swoją zaborczą polityką i wojskowym zagrożeniem dla sąsiadów sama postawiła kwestię ukraińską na pierwszym miejscu, która tak czy owak zostanie rozwiązana może w najbliższym czasie. Są dobre perspektywy, że już ta wojna wyzwoli z moskiewskiego jarzma część ukraińskich ziem".

23 „Jedno jest pewne, że naród ukraiński nie zginie, jak nie zginął dotąd i ma on przed sobą świetlaną przyszłość".

24 „Widzieliśmy, że sama natura umieściła Ukrainę na takim miejscu na całym świecie, że jest ona teraz dzięki nieuniknionym wydarzeniom historycznym na pierwszym miejscu”.

25 „To nadchodzi dla nas wielkie święto po takim cierpieniu, święto odnowienia naszego serca i duszy oraz święto odrodzenia narodowego".

26 „Gdy wojna w Galicji Wschodniej i na Bukowinie groziła strasznym nieszczęściem, to i wtedy nie udało się rosyjskim komendantom i odszczepieńcom zniszczyć wśród ludzi głęboko zakorzenionego uczucia ciągłości, które podsycali ich przywódcy, choć dobrzy sąsiedzi twierdzą inaczej”. 
te, które opisują pokój, zwycięstwo i niepodległość Ukrainy, na przykład: słońce wolności, Niezależna Ukraina, patrioci, pokój czy rozejm. Wojna zawsze kończy się bowiem pokojem, do którego wezwanie niezmiennie brzmiało w kronikach I wojny światowej:

А коли так, то ми мусимо витримати дальше і силою нашого оружа примусити ворогів до миру. Одначе знаймо, , що не ми, а наші вороги винні дальшому непотрібному проливові крови і тої нужди, яка стала на весь світ. Ми не дамо ся, бо за нами правда, отже й побіда ${ }^{27}$. (Календар 2007: 163)

Przełożyly Iryna Procyk i Anna Ursulenko

\section{Bibliografia}

\section{Źródła}

Бажанський I.M. (2006): Війна: Щоденник-хроніка буковинського педагога та письменника (Вашківці, 31.8.1914-29.11.1917), Чернівці.

Невідома війна. Перша світова війна на сторінках Православного буковинського календаря 1914-1918 (2007): Чернівці.

\section{Literatura}

https://pl.wikipedia.org/wiki/Ksi\%C4\%99stwo_Bukowiny (dostęp: 5.07.2017).

Oleś O., Крилаті вирази, вислови і цитати про життя і смерть, http://www.ukrlib.com.ua/encycl/ viraz/printout.php?id=11 (dostęp: 15.03.2017).

Wierzbicka A. (1991): Uniwersalne pojęcia ludzkie $i$ ich konfiguracje $w$ różnych kulturach, „Etnolingwistyka” nr 4, s. 7-40.

Фасмер М. (1967): Этимологический словарь русского языка, t. 1, Moskwa.

Іващенко В. (2006): Концептуальна репрезентація фрагментів знання в науково-мистецькій картині світу (на матеріалі української мистецтвознавчої термінологіi), Київ.

Яворська Г. (2000): Прескриптивна лінгвістика як дискурс: Мова. Культура. Влада, Київ.

Кононенко В. (2008): Українська лінгвокультурологія, Київ.

Космеда Т. (2010): Лінгвоконцептологія: мікроконцептосфера святки в українському мовному просторі, red. Т.А. Космеда, Н.В. Плотнікова, Львів.

Медвідь Н.Н. (2009): Лінгвокультуреми в українській соціально-психологічній прозі першої потовини ХХ ст, Київ.

Радзієвська Т. (2010): Нариси з концептуального аналізу та лінгвістики тексту: Текст - соиіум - культура - мовна особистість, Київ.

Селіванова О. (2006): Сучасна лінгвістика: термінологічна енциклопедія, Полтава.

Шевченко М. (2002): Семантичний та текстотворчий потенціал лінгвокультурем в украӥнському поетичному мовленні, Київ.

27 „A jeśli tak, to musimy wytrzymać jeszcze i mocą naszej broni przymusić wrogów do pokoju. Musimy wiedzieć, że nie my, lecz nasi wrogowie są winni dalszemu przelewaniu krwi i tej biedy, która zdarzyła się na całym świecie. Nie poddamy się, bo prawda i zwycięstwo są po naszej stronie”. 
Воробьев В. (1994): Культурологическая парадигма русского языка: Теория описания языка и культуры во взаимодействии, Москва.

Вислови, афоризми, загадки, http://vislovi.in.ua/prikazki-temi/54-vijsko.html (dostęp: 15.03.2017). Жайворонок В. (1996): Слово в етнологічному контексті, „Мовознавство” nr 1, s. 7-14.

\section{Lingvokulturem war chronicles Bukovyny: Blog-chronicle of John Bazhanskoho and Bukovina orthdox calendar}

\section{Summary}

The linguistic and cultural units war in the sphere of Ukrainian prose in the context of cognitive linguistic, linguistic culture and social linguistic with using of conceptual and cognitive approach is studied. This approach allows to model and reflect the structural elements of speech act participants' consciousness, it is based on the concept analysis, linguistic and cultural units, metaphorical models and stereotypes, which are the base of a specific conception.

Keywords: cognitive metaphor, linguistic and cultural unit, cognitive linguistic, metaphoric model. 